\title{
Implementation of Teaching Ketamansiswaan Tri-N to Instil Noble Characteristics of Students at SDN I Plumbon, Karanganyar District
}

\author{
Wachid Pratomo ${ }^{1)}$, Nadziroh ${ }^{2)}$, Chairiyah ${ }^{3)}$ \\ Elementery School Teacher Study Program Universitas Sarjanawiyata Tamansiswa, Indonesia ${ }^{1,2,3)}$ \\ putrieneliz37@gmail.com
}

\begin{abstract}
The purpose of this study was to determine the process of implementing Tri-N Student Teachings Ketamansiswaan Tri-N to Instil Noble Characteristics of SD N 1 Plumbon Students in Karanganyar Subdistrict, the obstacles encountered in implementing Tri-N Student Teachings to instil noble character of SD NI Plumbon students and to find solutions used to overcome obstacles in the implementation of Tri-N Student Teachings to instil the noble character of students of Plumbon Elementary School NI Karanganyar. This type of research is a type of qualitative research. The data used in this study are primary data, the data obtained directly from research subjects. The instrument of this study was the researcher himself, assisted by interview guidelines, questionnaires, observations and documentation. Methods of data analysis by data reduction, data presentation, drawing conclusions and verification as well as checking the validity of the data with triangulation techniques. The targeted output of this study is an accredited national journal. The results of the data analysis can be concluded that by using the right learning model, it can provide maximum learning outcomes. Learning model with the concept of $3 \mathrm{~N}$ (Niteni, Nirokke, Nambahi) can be applied in Civics learning. By applying this $3 \mathrm{~N}$ concept, students are expected to be able to carry out learning to the maximum that is observing learning objects, then imitating what students have observed, and the final stage of students can improve by adding to the learning object so that in teaching and learning process, students will produce knowledge and skills.
\end{abstract}

Keywords: Implementasion, learning Ketamansiswaan Tri-N,Noble Character

\begin{abstract}
Abstrak. Tujuan penelitian ini adalah untuk mengetahui proses pengimplementasian Ajaran Ketamansiswaan Tri-N untuk Menanamkan Budi Pekerti Luhur Siswa SD N 1 Plumbon Kecamatan Karanganyar, kendala yg dihadapi dalam pengimplementasian Ajaran Ketamansiswaan Tri-N unuk menanamkan budi pekerti luhur siswa SD N I Plumbon dan untuk mengetahui solusi yang digunakan untuk mengatasi kendala dalam pengimplementasian Ajaran Ketamansiswaan Tri-N untuk menanamkan budi pekerti luhur siswa SD N I Plumbon Kecamatan Karanganyar. Jenis penelitian ini adalah jenis penelitian kualitatif. Data yang digunakan dalam penelitian ini adalah data primer, yaitu data yang diperoleh langsung dari subjek penelitian. Instrumen dalam penelitian ini adalah peneliti sendiri dengan dibantu pedoman wawancara, angket, observasi dan dokumentasi. Metode analisis data dengan reduksi data, penyajian data, penarikan simpulan dan verifikasi serta pengecekan keabsahan data dengan teknik triangulasi. Luaran yang ditargetkan dalam penelitian ini adalah jurnal nasional terakreditasi. Hasil analisis data dapat disimpulkan bahwa menggunakan model pembelajaran yang tepat dapat memberikan hasil pembelajaran yang maksimal. Model pembelajaran dengan konsep $3 \mathrm{~N}$ (Niteni, Nirokke, Nambahi) dapat diterapkan dalam pembelajaran PKn. Dengan menerapkan konsep $3 \mathrm{~N}$ ini, diharapkan peserta didik dapat melaksanakan pembelajaran dengan maksimal yakni dengan mengamati obyek pembelajaran, kemudian menirukan apa yang telah peserta didik amati, dan tahap terakhir peserta didik dapat menyempurnakan dengan menambahi obyek pembelajaran tersebut, sehingga dalam proses pembelajaran peserta didik akan menghasilkan pengetahuan dan keterampilan. Kata Kunci: Implementasi, Ajaran Ketamansiswaan Tri-N, budi pekerti luhur.
\end{abstract}




\section{INTRODUCTION}

National education has the task of developing Indonesian people so that they become whole human beings and at the same time develop character resources. School as an educational institution is a vehicle for students who have a character in order to survive in the global era. Ministry of National Education (Kemdiknas) starting the new academic year 2011/2012, plans to implement character education. Character education material will be given starting from the level of early childhood education (PAUD) to university. Related to formal and non-formal education.

The realization of Indonesian society with noble character, noble character, and morality is the goal of the development of Indonesian society which is then implemented in the aim of national education. Character education to facilitate students to be able to use knowledge, study, internalize values, and personalize values, and develop social skills that enable the growth and development of noble morals in students and develop daily relationships (Nurul Zuriah, 2011: 65).

In principle, the current learning objectives are educational concepts taught by KI Hajar Dewantara since a long time ago. Learning outcomes to be achieved are cognitive (understanding), affective (Ngrasa), and psychomotor (nglakoni). This was further elaborated by Bloom's Taxonomy which had been revised in 2001. Each domain has developed into many indicators that are presented clearly and in detail using operational verbs. Cognitive processes (understanding) are arranged in stages including remembering, understanding, using, analyzing, assessing and creating. Dimensions of knowledge are facts, procedural concepts, and metacognition. Affective process (ngroso) is a process to achieve learning goals related to feelings, emotions, value systems and attitudes that indicate acceptance and rejection of something. Each level in a sequential manner in the affective process that is the level of receiving, responding, appreciating, organizing and living levels. The psychomotor domain is a learning goal related to motor skills including the movement of the whole body, coordinated movements, non-verbal communication and ability to speak.

Based on observations on May 7, 2019 at SD Negeri 1 Plumbon, Karanganyar District, there were some problems: students were still busy or noisy in learning when given assignments by the teacher the lack of concern for students to do well, if there were no homework students did not learning at home, students lack the sense of help to help, student activities have not been observed in internalizing noble character, there is still a lack of teacher's ability to maximize learning of virtuous character.

Tri-N Teachings are a concept of education taught by Ki Hajar Dewantara since ancient times consisting of niteni, nirokake and addi. The purpose of this study was to 
determine the process of implementing Tri-N to instill Budi Pekerti Luhur students at SD N 1 Plumbon Karanganyar.

In implementing noble mind and character through Tri-N, learning planning is needed. Learning activities which include introductory, core and concluding stages can be internalized in learning by incorporating choices from the values of character that want to be developed in learning. Development of the elements of character in learning include conscience, virtue, honesty, trustworthy, discipline, courtesy, neatness, sincerity, selfcontrol, courage, friendship, loyalty, honor and justice. Based on the problem, the researcher will conduct descriptive qualitative research through learning of noble mind and character by applying Tri-N in Teaching Students.

\section{RESEARCH METHODS}

This type of research was a type of qualitative research. The data used in this study were primary data,the data was obtained directly from research subjects. The instrument of this research was the researcher himself, assisted by interview, observation and documentation guidelines. Methods of data analysis by data reduction, data presentation, drawing conclusions and verification also checking the validity of the data with triangulation techniques.

\section{DISCUSSION}

Implementation

of

Teaching

Ketamansiswaan Tri-N to Instill Noble

Characteristics of Students at SD N 1

Plumbon Karanganyar District

In this research, the implementation of noble mind and character through Tri-N is the implementation of someone who What if you have knowledge about how to solve and remember something discussed (niteni) about something, then you must have a sense of wanting to do things following the knowledge you have. And not only to imitate something learned (nirokake), but try to develop something that is learned (added) from the knowledge gained.

This research, the implementation of noble mind and character through Tri-N is the implementation of someone who already has knowledge. Someone already has knowledge that is taken by way of recognizing and remembering something that is learned (niteni) about a thing, then it must have a sense of wanting to do things by the knowledge possessed. And not only to imitate something that is learned (nirokake), but also should develop something that is learned (nambahi) from the knowledge possessed.

Niteni means the process of finding meaning (traits, traits, procedures, truth) of an object observed through sensory means. Thus, niteni is a cognitive / thought process which according to $\mathrm{Ki}$ Hadjar Dewantara called Cipta. Cipta is the power of thinking, which is 
tasked with finding the truth of something by observing and comparing objects so that they can know the differences and similarities. Nirokke and addi can be translated as imitating (to imitate) and developing/adding (to innovate / to add value). The discussion of these two concepts was put together considering that nirokke and addi were in the same level, namely the application of the acquisition of the niteni process. According to Ki Hadjar Dewantara included in the realm of "Kemauan or Karsa" that always arise next to or as if the result of thoughts and feelings. The difference between the two lies in the degree and creative process. Nirokke or imitating according to Ki Hadjar Dewantara is a nature in childhood (Suroso, 2011). In relation to the process of imitating, especially children have the desire to always imitate everything that interests him. Most of the abilities, skills, and behaviour of children are the process of imitation, especially parents, for example talking, behaving, playing, and so forth. This imitation is very useful because it has the nature to educate oneself personally by way of orientation and experience even in a fantasy. Nambahior adding/developing is a further process of nirokke. In this process, there is a creative and innovative process to give a new colour to the model being emulated. This added process is expected to occur in students. In this case, Ki Hadjar Dewantara stated that we are not merely imitating, but processing. If we just copy it "copyeren", remember that the person who imitates, it is usually someone who has nothing of their own. If people have, on the contrary, they improve, add, reduce, change, and process something that is copied (Suroso, 2011).

The 3N concept (Niteni, Nirokke, Nambahi) in Civics Learning is considered an important science because it is an introduction to other sciences. In Civics learning, the $3 \mathrm{~N} \mathrm{Ki}$ Hadjar Dewantara concept can be used as a learning model. However, the application of the $3 \mathrm{~N}$ concept must be gradual, namely Niteni, Nirokke, then Nambahi. Each stage does not precede each other, because Nambahi is a final process that will produce intact knowledge and skills. The use of the $3 \mathrm{~N} \mathrm{Ki}$ Hadjar Dewantara concept in Civics learning is as follows:

1. Students listen to the teacher's explanation of the material being explained (Niteni activities)

2. Students are given an explanation of how to solve problems or problems related to the material described (Niteni activities)

3. Students are given examples of questions relating to the material presented taken from thematic books (Niteni activities)

4. Students make observations about the problems or problems related to the material presented. The teacher mobilizes students to pay close attention to the questions given (Niteni activities)

5. Students are asked to find the basic concepts of the material presented and the 
problems observed. The teacher guides students in determining the concept of the material presented (Niteni activities)

6. Students identify the use of appropriate concepts in given problems that have been observed. The teacher guides students in identifying the use of concepts from the problems observed (Niteni activities)\

7. Students arrange problem-solving with previously identified concepts that are observed with the guidance of the teacher (Nirokke activities)

8. Students write problem solving using the concepts that have been identified and then modified so that they are easily understood when relearning (Nambahi activities)

9. Students with the teacher conclude the problems that have been resolved in accordance with the material presented properly and correctly (Nambahi activities)

With the steps mentioned above, learning using the $3 \mathrm{~N}$ concept can train students' abilities through their five senses. The hope is from the niteni position, students can seek clarity from Civics objects through careful and in-depth observation. While from the nirokke process, students can imitate exactly from the objects that have been observed. Then in the process of adding, students can try to be creative in solving a Civics problem with knowledge that has been obtained from the niteni and nirokke processes.
The conditioning of learning carried out on the implementation of noble character is to foster the values of character as follows:

1. Having and developing tolerance. The teacher gives an example can be friendly with school residents who are religious, ethnic and cultural, give greetings when meeting with other teachers, students and other school residents, responding and answering greetings, giving advice. Students are directed to be accustomed to get along peacefully with other students who embrace different religions, cultures and tribes.

2. The growth of self-discipline. The teacher gives the example to arrive on time, always dress cleanly, neatly and politely, always maintain class cleanliness and behave in an orderly manner. Students are directed to be accustomed to not being late when entering school. Use clothes neat, clean and polite, get in the way and do not make noise.

3. Develop a work ethic. The teacher gives praise for the improvement of student achievement, encourages students to always study hard, compliments students who are diligent in doing assignments, the teacher does not give too much assessment and burdens students, students are directed to be accustomed to learning routinely to relearn what is obtained in class, do assignments as soon as possible, and make study groups work on assignments. 
4. Have a sense of responsibility. The teacher gives an example by checking and giving feedback, advises to do the task according to the instructions, advises not to cheat in doing the task, and directs to be able to do the task in accordance with the given task. Students are directed to be used to being able to submit assignments on time, to do assignments carefully and not to depend on others.

5. Have a sense of openness. Students provide an example by always providing opportunities for students to be able to express their opinions and provide a plus point for students who ask, answer and express opinions. Students are directed to be able to express their opinions properly and correctly and can respect the opinions of other friends both different and the same opinion with his thoughts.

6. Be Able to think positively. The teacher provides an example by giving praise to students who are able and willing to do good when helping others, creating a learning atmosphere that is warm, conducive, open and objective. Students are directed to be accustomed to interacting with lecturers and other students, and students want to understand and try to get used to positive thinking attitudes.

7. Develop self-potential. Students provide an example by providing support in instilling a sense of pleasure and develop the abilities of students by helping and training students in ongoing learning activities. Students are directed to get used to being active in the learning process.

8. Having togetherness and mutual cooperation. Students set an example by creating learning activities in groups on certain materials. The teacher participates in providing assistance and guidance when students experience learning difficulties.

9. Mutual respect. The teacher sets an example by speaking softly and being respectful of others, the teacher arranges and reminds students who act disrespectfully and do not ask permission when leaving learning in class.

10.Cultivating honesty. The teacher provides an example by encouraging students to always tell the truth in accordance with reality, praising every honest word made by students. Students are expected to be honest doing their own work and when given assignments in groups must also participate in working on the group assignments

\section{The implementing Obstacles in teachingKetamansiswaan Tri-N to Instill Noble Characteristics of Students at SD N 1 Plumbon Karanganyar District}

The implementing Obstacles in teachingKetamansiswaan Tri-N to Instill Noble Characteristics of Students at SD N 1 Plumbon Karanganyar Districtnamely 1). Lack of understanding that the cultivation of noble character, mind and body development 
of children can not be beaten flat, 2). Families often put forward the prestige and reputation of educational institutions to put aside the quality of education, 3). Schools tend to teach about temporary theories to pursue high score.

\section{Problem solving Sollution in teaching Ketamansiswaan Tri-N to Instill Noble Characteristics of Students at SD N 1 Plumbon}

Solutions to overcome obstacles in teaching Ketamansiswaan Tri-N to instill noble mind and character in students of SD NI Plumbon, namely: 1) Make a basic design of teaching with the basis and motto of Ki Hajar Dewantara (application of KHD Tri-N Instructions), 2) Emphasize that education is not only focused on cognitive aspects but also emphasized on the affective and psychomotor aspects, 3) Educators always try to be an example for their students and provide advice to behave well.

\section{CONCLUSION}

Using the right learning model can provide maximum learning results. Learning model with the concept of $3 \mathrm{~N}$ (Niteni, Nirokke, Nambahi) can be applied in Civics learning. By applying this $3 \mathrm{~N}$ concept, students are expected to be able to carry out learning to the maximum that is by observing learning objects, then imitating what students have observed, and the final stage of students can improve by adding to the learning object so that in the learning process students will produce knowledge and skills. It is suggested that the teacher needs to familiarize, pay attention to and further develop the implementation of character in every learning activity. Further research needs to be done on the implementation of noble mind and character in developing and applying values to develop students' potential in learning. To be able to develop niteni, nirokake and add to the students themselves there needs to be a continuous or continuous encouragement so that it will become a good habit for students in future community life.

\section{REFERENCES}

[1] Darmadi, Hamid. (2009). Dasar Konsep Pendidikan Moral. Bandung: Alfabeta.

[2] RI, K. (2011). Kementerian Pendidikan Nasional Republik Indonesia. 2010b). Pengembangan Pendidikan Budaya dan Karakter: Pedoman untuk Sekolah. Jakarta: Kemendiknas RI.

[3] Moleong J. Lexy. (2012). Metode Penelitian Kualitatif. Bandung: PT Remaja Rosdakarya.

[4] O’Neil, William F. (2008). Ideologi-Ideologi Pendidikan. Yogyakarta. Pustaka Pelajar.

[5] Samsuri \& Muchson, A.R. (2013). Dasardasar Pendidikan Moral BasisPengembangan Pendidikan Karakter. Yogyakarta: Ombak.

[6] Sudartomo, Macaryus. (2013). Kebudayaan Mendesain Masa Depan. Yogyakarta: UST Press-Majelis Luhur Persatuan Tamansiswa.

[7] Sugiyono. (2013). Metode PenelitianPendidikan Pendekatan Kuantitatif, Kualitatif, dan $R \& D$. Bandung: Alfabeta. 
[8] Suratman, Ki. (1992). Dasar-Dasar Konsepsi Ajaran Ki Hajar Dewantara.Yogyakarta: Majelis Luhur Persatuan Tamansiswa

[9] Susanto, Ahmad. (2013). Teori Belajar dan Pembelajaran di Sekolah Dasar. Jakarta: Kencana Predana Media Group.

[10] Suroso, D. A., \& Nashori, F. (2011) Psikologi Islam Solusi Islam Atas ProblemProblem Psikologi. Yogyakarta: Pustaka Pelajar.

[11] Tauchid, Moch. (1967). Karya Ki Hadjar Dewantara.Yogyakarta. Majelis-Luhur Persatuan Tamansiswa.

[12] Tim Dosen Ketamansiswaan. (2014). Materi Kuliah Ketamansiswaan.Yogyakarta: UST Press

[13] UU No.20 Tahun (2003) tentang UndangUndang Sistem Pendidikan Nasional

[14] Zuchdi, Darmiyati. (2001). Humanisasi Pendidikan moral. Yogyakarta: UNY Press.

[15] Zuriah, Nurul. (2007). Pendidikan Moral \& Budi Pekerti Dalam Perspektif Perubahan. Jakarta: PT Bumi Aksara 